\title{
The Politics of Appropriation: Erasmus and Bayle
}

\author{
Wiep van Bunge \\ Professor, History of Philosophy, Erasmus University, Rotterdam \\ vanbunge@fwb.eur.nl
}

\begin{abstract}
Over the centuries, the local elites of Rotterdam have gone out of their way to cultivate the memory of Erasmus. From the sixteenth century onwards to this day, he has been consistently put forward as the city's greatest son. During the early 169o's, when Pierre Bayle, "le philosophe de Rotterdam", was facing dismissal as professor of the Illustrious School of Rotterdam, he launched an attempt to save his position by reminding his employers of his allegiance to Erasmus' heritage. Although Bayle would be fired just the same, we have every reason to take his Erasmianism seriously. In particular, Bayle's critical attitude as an historian is reminiscent of Erasmus' philological stance.
\end{abstract}

\section{Keywords}

appropriation - Bayle - Enlightenment - Erasmus - fideism - pacifism - philosophy Rotterdam - Republic of Letters - scepticism

\section{Introduction: Erasmus of Rotterdam}

Being an inhabitant of this city suffices to create a connection with Erasmus: we, as Rotterdammers, travel from the northern part of our city to the other side via the Erasmus Bridge. All my three children were born in the Erasmus Medical Center, and our eldest son is now a pupil of the Erasmiaans Gymnasium. On my way to work, I used to pass a (rather seedy) pub called 'Erasmus', and I can point you the way to the Erasmusstraat, the Erasmuspad and even an Erasmussingel, all located in Rotterdam, which over the centuries has gone out of its way to cherish the memory of its greatest son. ${ }^{1}$ Only four years ago, in

1 Cf. Willem Frijhoff, Heiligen, idolen, iconen, Nijmegen, 1998, pp. 6o-63. 
October 2008, the city of Rotterdam showered its citizens with a wide variety of events, celebrating the birthday of Erasmus and his memory: on the 28th of that month several hundreds of pupils of the Erasmiaans Gymnasium swarmed out all over the city, lecturing at primary schools on Erasmus' Life and Work, acting as 'ambassadors' of 'Erasmianism'. On the same day an 'Erasmushuis' was opened, opposite the Laurence Church and the famous statue of Erasmus by Hendrick de Keyser. ${ }^{2}$ The Museum Boijmans Van Beuningen brought together a splendid exhibition, celebrating Erasmus and the sixteenth century, ${ }^{3}$ and in the same month the highly prestigious Praemium Erasmianum was awarded to Ian Buruma in Rotterdam - on that occasion he held a lecture on modern day cosmopolitanism. ${ }^{4}$ It goes without saying that he made more than a passing reference to Erasmus.

And yet, according to a survey held in $2003,65 \%$ of the Rotterdam population have no idea who he was. Apparently, most inhabitants of our city seem to believe that Erasmus actually built the bridge named after him. To tell you the truth, I am not at all sure what this figure tells us, either about Rotterdam or about Erasmus. For it also means that over a third of the population is more or less aware of his identity — not bad at all, I would say, for a city about half of whose current inhabitants are of non-European descent. Since the second half of the sixteenth century, Erasmus has been cherished by Rotterdam, in particular by the local elites, as is evident for example from the very existence of the Erasmus collection, which is kept at the municipal library of Rotterdam. I am told it is the largest collection of Erasmiana in the world. ${ }^{5}$ Its catalogue has now been digitalised and work is under way to put its main treasures online. This collection holds over 16,00o items and goes back to 1604, when the Rotterdam 'vroedschap', that is its city council, opened a public library in the Laurence Church. In 1814 a catalogue was issued, listing only seven editions of Erasmus. During the 19th and early 2oth centuries, however, some 700 Erasmiana were added, and in the 1920s and early 1930s another 1,000 items were purchased, thanks to the largesse of local entrepreneurs and industrialists: the collection as it stands today has been largely financed from private means. ${ }^{6}$ To this day,

2 http://www.erasmushuisrotterdam.nl/.

3 Peter van der Coelen (ed.), Images of Erasmus, Rotterdam, 2008.

4 http://www.erasmusprijs.org/eng/index.htm.

5 http://www.erasmus.org/.

6 J.J.M. van de Roer-Meyers, 'De Erasmuscollectie van de Gemeentebibliotheek Rotterdam', Rotterdams Jaarboekje, 1985, pp. 259-265. See also N. van der Blom, Erasmus en Rotterdam, Rotterdam, 1969, Chapter 9. 
the Erasmusstichting is a major sponsor of all sorts of cultural initiatives in Rotterdam and of efforts related to Erasmus in particular. ${ }^{7}$

The most obvious illustration of the iconic status Erasmus has acquired in the Netherlands, and in Rotterdam in particular, is of course supplied by the history of the various statues the city erected in his honour. This history has been studied in depth: when in 1622 the present monument-which was actually the fifth of its kind - was put into place, the Calvinist clergy objected strongly on the grounds that Erasmus had held 'remonstrant' sympathies. But the city's mayors typically refused to listen to such objections, and decided to leave the statue where it was - a remarkable decision in view of the dramatic outcome of the Synod of Dordrecht just three years earlier, in 1619, which sealed the fate not only of Hugo Grotius but of the entire Arminian faction within the Dutch reformed Church as well as within Dutch society, although in 1630, in Rotterdam, the Remonstrant Fraternity was established, and allowed to grow into a minor denomination, which would continue to serve as the liberal wing of the Dutch Reformed Church to this day. ${ }^{8}$

When during the late 1960s a new university emerged from the cooperation between the newly established medical faculty and the local School for Economics, it actually took quite some time to come up with a suitable name, and the economists in particular were afraid that the loss of their old name, Nederlandse Economische Hogeschool, would hurt their reputation. In the end, however, it appears to have been the political and financial elites of the city who won the day. After mayor Wim Thomassen in 1968 had first suggested the name of Erasmus for this University in the making, several 'prominent citizens' of Rotterdam made sure that in November 1973, the University of Rotterdam opened its doors as the Erasmus Universiteit Rotterdam. The letter they addressed in 1972 to the Dutch Minister of Education is a fine example of local, civic pride, but it also demonstrates an acute awareness of the prevailing image of Rotterdam as a city dedicated to 'commerce and traffic, rather than science. ${ }^{9}$ Today, Erasmus has become one of the icons of toleration cherished well beyond the traditional Rotterdam elites who over the centuries have made sure that this city would remain associated with its greatest son.

7 http://www.erasmusstichting.nl/.

8 N. van der Blom, 'De beelden van Erasmus', Florislegium. Bloemlezing uit de Erasmiaanse, Rotterdamse en andere opstellen, Leiden, 1982, pp. 29-54. See more recently Paula Koning, Erasmus op de markt, Rotterdam, 2009.

9 M. Davids en J. van Herwaarden, Erasmus Universiteit Rotterdam, 1973-1993, Rotterdam, 1993, pp. $5^{-6 .}$ 
Dutch intellectuals and politicians have always found it difficult to resist the temptation of turning Erasmus into the quintessentially Dutch advocate of toleration. Especially during the 1930 great professional historians such as Johan Huizinga and Jan and Annie Romein liked to muse about 'the Erasmian spirit' pervading Dutch history, and it goes without saying that according to such accounts, this 'Erasmianism' reached its zenith during the Golden Age of the Dutch Republic, when the lack of religious unity, or so we were told, actually served as a powerful engine for turning the Republic into the most liberal and most adventurous cultural arena of its time..$^{10}$ Increasingly, however, the experts on Erasmus have been calling for caution. Over the last few years Jan van Herwaarden in particular has gone out of his way to emphasise that Erasmus' comments on Judaism and Islam seriously complicate any attempt to turn him into an early modern 'multiculturalist.' ${ }^{11}$ In a fine essay on the practice of toleration during the latter half of the sixteenth and the first part of the seventeenth century, Nicolette Mout also showed little patience with a naïve understanding of the place of non-Calvinists in a Calvinist society, arguing that this issue

was only settled in favour of toleration because in the Dutch Republic, unlike its neighbouring countries, two things were lacking: a consensus fixed in a detailed and comprehensive religious settlement, or a state church imposing its will. That lack of consensus and tension between the privileged church and the secular authorities were responsible for such a remarkable phenomenon as toleration is the genuine miracle of the Dutch Republic. ${ }^{12}$

Recently, Benjamin Kaplan turned this scepticism regarding the relevance of early modern intellectual strategies to come to terms with the challenge of religious diversity into the basis of a radically pragmatic account of the

10 See, most notably, Jan en Annie Romein-Verschoor, Erflaters van onze beschaving, 4 vols., Amsterdam, 1938-1940, but also Johan Huizinga, Erasmus, Haarlem, 1924 and Nederland's beschaving in de zeventiende eeuw, Haarlem, 1941. See on Huizinga's obsession with the Dutch identity Anton van der Lem, Het eeuwige verbeeld in een afgehaald bed. Huizinga en de Nederlandse beschaving, Amsterdam, 1997.

11 See, for instance, Jan van Herwaarden, Between Saint James and Erasmus. Studies in LateMedieval Religious Life: Devotion and Pilgrimage in the Netherlands, Leiden, 2003, Chapter 14. 12 M.E.H.N. Mout, 'Limits and Debates: A Comparative View of Dutch Toleration in the Sixteenth and Early Eighteenth Centuries', C. Berkvens-Stevelinck, J. Israel and G.H.M. Posthumus Meyjes (eds.), The Emergence of Tolerance in the Dutch Republic, Leiden, 1997, pp. 37-47, p. 47. 
politics of toleration of sixteenth and seventeenth-century Europe in which, remarkably, Erasmus is barely mentioned. According to Kaplan, there was no 'rise of tolerance' culminating in the Enlightenment, nor was toleration the outcome of philosophical or theological reflection of any kind. Instead we are best advised, Kaplan feels, to study toleration as 'a form of behavior', 'a social practice, a pattern of interaction among people of different faiths', that 'had a complex relationship to both ideals and official policies'. In Kaplan's view, early modern toleration 'was a pragmatic move, a grudging acceptance of unpleasant realities, not a positive virtue.'13

Returning to Erasmus, Mario Turchetti, in a much quoted paper on Erasmus' stance toward toleration, famously called the entire issue 'une question mal posée. ${ }^{14}$ In the Dutch context, however, there seems little doubt that the highly particular reception of Erasmus' works did turn him into an evident and early champion of the principle of toleration. For once Coornhert and Grotius had appropriated his heritage, he became one of the founding fathers of an intellectual tradition that may well have been as irrelevant to daily practice in the Dutch Republic as Kaplan concludes it to have been, but which did not fail to affect the self-image of the Dutch liberal elites throughout the centuries. As James Tracy has demonstrated, faced with the budding Reformation, Erasmus took an important first step toward a genuine theory of toleration by supporting the notion of mutual forbearance of religious minorities, which was subsequently picked up and elaborated upon in the 1580 s by Coornhert, arguing in favour of 'freedom of conscience in the full sense of the term. ${ }^{15}$

In the early decades of the seventeenth century Grotius turned to Erasmus as well. Hans Trapman, however, has demonstrated that we should not overestimate his importance to Grotius, pensionary of Rotterdam from 1613 until his arrest in 1618, who most notably in his huge correspondence hardly ever mentions Erasmus. Yet the way in which Grotius modelled Erasmus into an ancestor of Arminianism surely must have been crucial to the ongoing process of Erasmus' canonisation. As pensionary of Rotterdam, he was responsible for the assignment to Hendrick de Keyser to produce the final, bronze statue

13 Benjamin Kaplan, Divided by Faith. Religious Conflict and the Practice of Toleration in Early Modern Europe, Cambridge Mass., 2007, Introduction.

14 Mario Turchetti, 'Une Question Mal Posée: Erasme et la Tolérance. L'idée de Sygkatabasis', Bibliothèque d'Humanisme et Renaissance 53 (1991), pp. 379-395.

15 James D. Tracy, 'Erasmus, Coornhert and the Acceptance of Religious Disunity in the Body Politic: A Low Countries Tradition?', Berkvens-Stevelinck et al (eds.), The Emergence of Tolerance, pp. 49-62. 
of Erasmus. Once Erasmus had been associated by Grotius both with a liberal interpretation of divine predestination and with an 'accommodating' approach to the relationship between church and state, Erasmus seems to have become such an obvious ally of the liberal faction in Dutch theology and politics that it no longer became necessary to actually read his work. ${ }^{16}$ During the second half of the seventeenth century, Rotterdam became the centre for a circle of 'Erasmian' friends, consisting of liberal Mennonites and remonstrants who came together at the shops of the booksellers Frans van Hoogstraten and Isaac Naeranus. They included rich and powerful politicians such as Adriaan Paets and Grotius' son Pieter de Groot, but also slightly less august Collegiants such as the poet Joachim Oudaen, the merchant Jan Dionysz Verburg and the surgeon Jacob Ostens. ${ }^{17}$ Jori Zijlmans has demonstrated the extent to which a shared admiration for Erasmus brought them together. (According to contemporary Calvinists, these Rotterdam 'Erasmians' were actually Socinians in disguise.) From the 1650 s to the 1670 s they formed a clearly distinguishable social network that was largely defined by the spirit of toleration cultivated during the stadholderless period and against the background of a nascent radical Enlightenment which during the 168 os would more or less rip this network apart, once they started discussing the views of Spinoza. ${ }^{18}$

\section{Bayle on Erasmus}

Even such a well trodden path as the story of Erasmus' 'presence' in his place of birth over the centuries turns out to have its own unexpected byways. For just a few years ago, a letter was discovered, written by a Frenchman who was nicknamed le philosophe de Rotterdam, that to my taste brilliantly illustrates the real political use that was still made of Erasmus' heritage a century and a half after his death, at a time of great political, religious and social turmoil. On 5 December 1692, Pierre Bayle wrote a letter to a member of the Rotterdam vroedschap, in which he tried to avert his impending dismissal as professor of the local Illustrious School by evoking Erasmus' memory. Exactly 11 years earlier, on 5 December 1681, Bayle had delivered his inaugural address at this

16 J. Trapman, Het land van Erasmus, Amsterdam, 1999, Chapter 2.

17 Jori Zijlmans, Vriendenkringen in de zeventiende eeuw. Verenigingsvormen van het culturele leven te Rotterdam, The Hague, 1999, Chapter 7.

18 Wiep van Bunge, Johannes Bredenburg (1643-1697). Een Rotterdamse collegiant in de ban van Spinoza, Rotterdam, 1990. 
newly established school, that was meant to prepare its pupils for university. He had been hired by the Rotterdam regent Adriaan Paets, whose cousin had alerted him to a young French professor of Philosophy from the Protestant university of Sedan who was in dire need of an academic position now that for Protestants life was becoming increasingly intolerable in France. At the time, Bayle was perfectly obscure for the simple reason that he had not published, but immediately after his arrival he started making a name for himself as a force to be reckoned with in the Republic of Letters: during the 168 os he published his famous Lettre sur les comètes, the Nouvelles de la République des Lettres as well as his Commentaire philosophique, a brilliant and incisive defence of religious toleration. His teaching duties were minimal since he only lectured on Friday mornings, to a handful of pupils, so he had ample time and opportunity to quickly gain a formidable reputation as a scholar and a polemicist. ${ }^{19}$

But many of his views found opposition among his fellow réfugiés, including most notoriously his one time friend and ally, Pierre Jurieu. This Walloon minister had developed many grievances against Bayle's views, none of which he found more repelling than the latter's conviction that atheism did not necessarily lead to immoral behaviour. Following William III's Glorious Revolution of 1688 , the political situation of the Refuge took on a completely new dimension, opening up the possibility, or so it seemed to Jurieu and his supporters, of starting a common, Protestant, Northern European offensive against the wicked King of France who was responsible for the Revocation of the Edict of Nantes in 1685. Bayle on the other hand was a true 'Erasmian' in his disgust of war, and he continued to argue in favour of tolerance. To Bayle's mind, a truly tolerant Christian even endured the horrors of Catholicism and atheism. After several years of campaigning against this kind of dogmatic laxity, Jurieu managed to convince the Rotterdam vroedschap that le philosophe de Rotterdam had forfeited his rights to instruct its sons. He just had to be fired, and after an Orangist purge of the vroedschap occasioned by the violent 'Costerman riots' of 1690, Bayle's future as a professor at the Illustrious School looked very bleak indeed.

Since Bayle by this time had started working on his magnum opus, the Dictionnaire historique et critique, it has often been put as if Bayle could not

19 We now have two detailed biographies at our disposal: Élisabeth Labrousse, Pierre Bayle I. Du Pays de Foix à la cité d'Erasme, Dordrecht, 1985 (1963) and Hubert Bost, Pierre Bayle, Paris, 2006. See also H.C. Hazewinkel, 'Pierre Bayle à Rotterdam', Paul Dibon (ed.), Pierre Bayle, le philosophe de Rotterdam. Études et Documents, Amsterdam, 1959, pp. 20-47; Hans Bots, De Fransman Pierre Bayle en Nederland. Over een problematische verhouding en de betekenis van Bayles denken toen en $\mathrm{nu}$, Nijmegen, 2005 . 
care less: his publisher Reinier Leers had taken care of him financially and he only earned a meagre 500 guilders a year from the city council. ${ }^{20}$ Yet the letter I just mentioned, that came to light only a few years ago, tells a different story-a story in which Erasmus plays a crucial role. Apparently, Bayle felt perhaps the magistrates of Rotterdam could still be persuaded to reinstall him in his office, and on 5 December, 1692 he took his chance to convince his employers that it would be wrong to fire him. ${ }^{21}$ Apart from the fact, Bayle wrote, that Jurieu is mistaken, I simply have no time to do harm to the Republic, for over the last few years I have been working day and night on a massive project that takes all my time and will only enhance the lustre of Rotterdam. What is more, I have recently published a first sample of what I am working on, and in this sample I have praised Rotterdam abundantly and added a major article on Erasmus:

et je suis seur que par tout où l'on verra le Dictionnaire critique que je compose, on louera les magistrats qui auront fourni à l' auteur le repos, la protection, et la subsistence qui lui etoient necessaries (..) J' ose encore dire, Monsieur, que ceux qui ont vu à quoi je travaille seroient surpris que la florissante ville de Rotterdam bien loin de me favoriser dans ce dessein, m' eust oté cinq cent francs qu' elle me donne, qui seroit une epargne de rien pour une ville comme celle là.

In order to drive his point home, he added to his letter a copy of his first sample of the Dictionnaire, so that 'Monsieur' could take a look for himself. This book, entitled Projet et Fragments d'un Dictionnaire critique and published in the summer of 1692, does indeed contain a major, highly flattering essay on Erasmus and his special relevance to the city of Rotterdam: how happy, Bayle mused, Erasmus would have been about the establishment on 5 December 1681 of a proper Illustrious School in his native city, a school, moreover, that had even had the good sense to appoint a Professor of Philosophy and History! ${ }^{22}$

But neither the pre-publication of a sample of the Dictionnaire nor his personal ties to the vroedschap could save his career. Adriaan Paets had died

20 See on Leers: Otto S. Lankhorst, Reinier Leers (1654-1714). Uitgever en boekverkoper te Rotterdam, Amsterdam, 1983.

21 A part of this letter was first published in 'L'Affaire Bayle'. La bataille entre Pierre Bayle et Pierre Jurieu devant le consistoire de l'Église wallonne de Rotterdam. Texte établi et annoté par Hubert Bost. Introduction par Antony Mckenna, Saint-Étienne, 2006, pp. 55-56. Here, a different part will be quoted. The entire text is to be found in Pierre Bayle, Correspondance, eds. Élisabeth Labrousse, Antony Mckenna et al., vol. 8, Oxford, 2010, pp. 676-678.

22 Pierre Bayle, Projet et Fragments d'un Dictionnaire Critique, Rotterdam, 1692, pp. 254-255. 
in 1686, and although Bayle was on good terms with such influential local magistrates as Josua van Belle and Isaac Hoornbeek, he chose to address the central figure in the Costerman riots: Jacob van Zuylen van Nijevelt, one of the staunchest local Orangists of his day and, it must be said, one of the most horribly corrupt public officials who ever served the city of Rotterdam. ${ }^{23}$ Van Zuylen was generally perceived as a man who mainly served his own interests - from 1676 to 1690 he was bailiff (baljuw) as well as sheriff (schout), which made him a very rich man. The general revulsion over the man's greed and dishonesty took a violent turn in October 169o, following the execution of Cornelis Costerman, a member of the civil guard. During a nightly patrol of the guard a fight broke out in which a man was stabbed. Costerman pleaded guilty — as a guard he was only doing his job — and within several weeks he was beheaded. ${ }^{24}$ The populace was outraged at the severity of the ordeal, and over a dozen pamphlets were published, some written by such radical authors as Eric Walten and the young Bernard Mandeville, but despite the general revulsion over Van Zuylen van Nijevelt's behaviour-his house was sacked and looted by an angry mob-his personal ties with William III let him off the hook, and in October 1692 he was actually reinstated as bailiff. Backed by the stadholder and newly crowned King of England, he even succeeded in having his opponents, most notably Pieter de Mey, removed from the vroedschap. In addition he was awarded the massive sum of 152,000 guilders to make up for his losses.

On 30 October 1693, Bayle was fired-Van Zuylen van Nijevelt never took the trouble to respond to Bayle's plea, and the only reason I can think of why Bayle chose to address Van Zuylen, of all people, was his power: Bayle wrote his letter several weeks after the man's reinstatement. When, however, almost to a day three years later the first copies of the Dictionnaire became available, it became evident that Bayle persisted in his praise of Erasmus. The article itself is largely identical to the one first published in the Projet et Fragments, but not entirely. It emphasises Erasmus' pacifism to the extent that, for a Protestant, Bayle shows a remarkable understanding of Erasmus' refusal to join Luther during the $1520{ }^{25}$ Perhaps, cornered by Calvinist zealots, even the Protestant Bayle was able to appreciate Erasmus' fears of reformatory intolerance. In many meandering footnotes Bayle settled various disputes concerning Erasmus' biography. Bayle's

23 See on these magistrates E.A. Engelbrecht, De vroedschap van Rotterdam, 1572-1795, Rotterdam, 1973 .

24 Rudolf Dekker, 'Schijnheilig atheïst. Bernard Mandeville als pamflettist tijdens het Costermanoproer in Rotterdam in 169o', Holland 26 (1994), pp. 1-17.

25 Pierre Bayle, Dictionnaire historique et critique, Rotterdam, 1702, p. 1157, notes (T) and (V). This is the second edition, the last to have been seen through the press by Bayle himself. 
article on Rotterdam supplies further evidence of his admiration as well as of his awareness of the stature of Erasmus in his place of birth, supplying historical data on the house he was born in and on his statue:

Rien ne l'a fait connoître que d'avoir été la patrie du grand Erasme. Elle n'a pas été insensible à cette gloire. Elle a bien fait son devoir pour honorer la memoire de cet illustre personage, dont elle reçoit un si grand éclat. ${ }^{26}$

As far as Bayle's treatment of Erasmus' life is concerned, the first thing to notice is the candour with which he addresses his ancestry: 'On ne peut nier qu' il ne soit bâtard. ${ }^{27}$ On the basis of Paulus Merula's Vita Erasmi of 1607 and Scriverius' emendation of the same text of $1615,{ }^{28}$ Bayle chastises the efforts by some of Erasmus' rivals (such as J.C. Scaliger, who held notoriously inflated ideas about his own family tree) to put him down as 'just' a bastard. Next, Bayle congratulates the city of Rotterdam on its good fortune in having been able to provide shelter to Erasmus' mother when she was with child, but without a husband. In a passage that did not make it into the Dictionnaire, ${ }^{29}$ Bayle notes that Rotterdam's claim on Erasmus was, most of all, timely:

Roterdam a compris de bonne heure ses interêts, et a tellement affermi pendant que les choses étaient fraîches les titres de sa possession et la gloire qui lui revient d'être la patrie de ce grand homme, qu'on ne peut plus luy rien disputer sur ce sujet. Il a falu être alert, car le tems aurait pu verser mille tenebres sur une naissance comme celle-là. ${ }^{30}$

In another passage that only occurs in the Projet et Fragments, Bayle goes even further. He is critical of the many Dictionaries which did not duly recognise the exceptional care Rotterdam has taken to honour Erasmus. Bayle writes of the 'soin' the city has shown 'de témoigner combien elle se sent honorée d'être la patrie d' un si grand homme' Here, his prose almost becomes sticky:

26 Bayle Dictionnaire, pp. 2617-2619.

27 Ibid., p. 1149.

28 See most recently Paula Koning, 'De twee levens van Erasmus in Leiden. Petrus Scriverius en Paullus Medula als biogafische beeldvormers', De zeventiende eeuw 27 (2011), pp. 37-48.

29 Bayle, Dictionnaire, art. Erasmus, rem. L, p. 1153 allows him to add some further data to the Projet et Fragments, after l' abbé Nicaise had sent him extra information on Erasmus' reaction to Scaliger's attack in particular.

3o Bayle, Projet et Fragments, p. 231. 
On voit par là le bon goût qui regne depuis lontems parmi ceux qui la gouvernent, et l'on peut dire que l'honneur qu'elle s'est fait par les monumens qu' elle a consacrez à la gloire de ce héros de la Republique des Lettres est aussi grand ou même plus grand que celuy qu'il a fait à sa patrie. ${ }^{31}$

For Rotterdam has not only preserved the house Erasmus was born in, it also re-named its ancient Latin School in his honour, and finally it even erected a statue to the man.

Elsewhere in the Dictionnaire, Erasmus is quoted very often indeed. The University of Chicago has put the fifth and final edition of 1730 online, and the accompanying Full Text Search Form yields 93 hits on 'Erasme', and 894 on 'Erasmus' - a clear indication of Erasmus' presence in the Dictionnaire. ${ }^{32}$ I trust you will agree that this is not the occasion for a full analysis of the nearly 1,00o times Bayle refers to Erasmus. Unsurprisingly, a large majority of these references concern (near) contemporaries of Erasmus in such articles as Agricola (Rodolphe), Béda (Noël), Berquin (Louis de), Budé (Guillaume), Castellan (Pierre), Eppendorf (Henri d'), Geldenhaur (Gerard) and Luther (Martin), and then there is, of course, the separate article on the great city of Rotterdam. But also in several articles relating to Classical Antiquity, including Alcinous, Diogène, Junon and Virgile, Bayle abundantly demonstrates that he knew Erasmus' work well and put this knowledge to good use.

Bayle's article on Erasmus served as a milestone: it became an authoritative text on Erasmus' biography as well as a crucial source for the way in which Erasmus was dealt with, for instance in the Encyclopédie and by Voltaire, in his Essai sur les moers et les esprits des nations. ${ }^{33}$ While Bruce Mansfield is certainly right to argue that Bayle himself cannot be accused of modelling Erasmus into a proto-Enlightenment thinker, both Louis, Chevalier de Jaucourt, who wrote the article on Erasmus (that is on Rotterdam) for the Encyclopédie, and Voltaire thought nothing of literally copying large parts of Bayle's entry. Thus

31 Ibid., p. 253 .

32 http://artfl-project.uchicago.edu/node/79.

33 Bruce Mansfield, Phoenix of his Age. Interpretations of Erasmus, c1550-1750, Toronto, 1979, Chapter 8 and Man on his Own. Interpretations of Erasmus, c1750-1920, Toronto, 1992, Chapter 3. See also Nicolaas van der Blom, 'Rotterdam and Erasmus. Some Remarks', J. Sperna Weiland and W.Th.M. Frijhoff(eds.), Erasmus of Rotterdam. The Man and the Scholar, Leiden, 1988, pp. 240-252; Barbara Sher Tinsley, Pierre Bayle's Reformation. Science and Criticism at the Eve of the Enlightenment, Cranbury N.J., 2001, Chapter 1. 
Erasmus was turned into a precursor of the Enlightenment after all, for Voltaire in particular shared none of the religious sensitivities of Bayle's assessment of Erasmus. ${ }^{34}$ Bayle's reaction to Erasmus seems to reveal a highly specific congeniality: while his former friend Jean Le Clerc, editor of Erasmus' Opera Omnia from 1703-1706, could revert to the Dutch humanist as a precursor of Arminianism, Bayle could not, for he denied the freedom of the will and he was highly suspicious of any attempt to rationalise faith in the way Le Clerc tended to do. This is why Élisabeth Labrousse went so far as to call Bayle 'un Erasme qui composerait le traité du Serf-Arbitre. ${ }^{35}$

\section{Erasmus and Bayle in the Republic of Letters}

Clearly Bayle's appropriation of Erasmus was also marked by the politics of his personal predicament, for by the 169os le philosophe de Rotterdam was in urgent need of respectable intellectual ancestry, and Erasmus, source of civic pride to the local elites to this very day, fitted the bill perfectly. Like Erasmus, Bayle must have felt a victim of belligerent, dogmatic theologians, but unfortunately Bayle's position mattered little to the local magistrates, who were caught up themselves in a violent battle for power. Le philosophe de Rotterdam, however, seems to have been aware of an affinity with Erasmus that was far more fundamental. In the first place, both authors shared a fideist scepticism as regards the apologetic potential of reason and of speculative metaphysics in particular. Precisely Bayle's recognition of Erasmus' fideist tendencies was largely ignored by the eighteenth-century philosophes, and as far as I can see, it was not until the rediscovery of the history of early modern scepticism by the late great Richard Popkin that the coherence of The History of Scepticism from Erasmus to Bayle would be recognised again. ${ }^{36}$ Erasmus' lack of fervour

34 See, more in general, Élisabeth Labrousse, 'Reading Pierre Bayle in Paris', A.C. Kors and P.J. Korshin (eds.), Anticipations of the Enlightenment in England, France and Germany, Philadelphia, 1987, pp. 7-16. For a fundamental reassessment of Voltaire's stance towards Bayle, see Jonathan I. Israel, Enlightenment Contested. Philosophy, Modernity, and the Emancipation of Man, 1670-1752, Oxford, 2006, Chapter 3.

35 Élisabeth Labrousse, Pierre Bayle. Hétérodoxie et rigorisme, Paris, 1996 (1964), p. 415.

36 The first edition (1960) of his History of Scepticism was entitled From Erasmus to Descartes, the second From Erasmus to Spinoza, and the final edition: The History of Scepticism. From Savonarola to Bayle, Oxford, 2003. 
for theological disputes informed by philosophy fits hand in glove with Bayle's critique of Scholasticism, put forward for instance in his article on Aristotle in the Dictionnaire. ${ }^{37}$

Secondly, Bayle was deeply impressed by Erasmus' pacifism. Bayle was disgusted with the religious wars of the early modern age:

Une des plus belles dissertations que l'on peut lire est celle d'Erasme sur le proverbe, Dulce bellum inexpertis. Il y fait voir qu' il avoit profondement medité les plus importants principes de la raison et de l'Evangile, et les causes les plus ordinaires des guerres. Il fait voir que la mechanceté de quelques particuliers, et la sottise des peuples produisent presque toutes les guerres, et qu' une chose dont les causes sont si blâmables, est presque toujours suivie d'un très-pernicieux effet. Il prétend que ceux que leur profession devroit le plus engager à déconseiller les guerres, en sont les instigateurs. ${ }^{38}$

This is the 'Erasmianism' appropriated by both Huizinga and Romein, who turned to Erasmus as a prime witness in their attempt to create an essentially pacifist national past. During the 1930s Huizinga and Romein were clearly challenged by the real threat of a German Anschluss. Huizinga especially set out to create a national narrative centering on the essentially 'burgerlijk' (civic) nature of Dutch culture alien to contemporary German ambitions. ${ }^{39}$ Over the past few years, the issue of 'our' national identity has again become the subject of heated debate. From a political perspective, I applaud the initiative of the Erasmiaans Gymnasium to turn its pupils into ambassadors of toleration in the name of Erasmus, and personally I was all in favour of the city's efforts to turn the Erasmushuis into an instrument in the ongoing accommodation of its non-European newcomers, as long as we agree that such initiatives are

37 For a recent summary, see Carlos Steel, 'Erasmus and Aristotle', Enrico Pasini and Pietro B. Rossi (eds.), Erasmo da Rotterdam e la Cultura Europea, Florence, 2009, pp. 149-174, 158: 'Erasmus' ambivalent attitude to Aristotle is in fact an indication of his ambivalent attitude to philosophy.'

38 Bayle, Dictionnaire, art. Erasmus, rem. V, p. 1157.

39 Remieg Aerts and Henk te Velde (eds.), De stijl van de burger. Over burgerlijke cultuur vanafde Middeleeuwen, Kampen, 1998; Joost Kloek and Karin Tilmans (eds.), Burger. Een geschiedenis van het begrip 'burger' van de Middeleeuwen tot de 21ste eeuw, Amsterdam, 2002. See also M.E.H.N. Mout, 'Erasmianism in Modern Dutch Historiography', M.E.H.N. Mout, H. Smolinsky and J. Trapman (eds.), Erasmianism: Idea and Reality, Amsterdam, 1997, pp. 189-198. 
indeed essentially political. We should, however, also acknowledge the highly particular irony in this history of 'Erasmianism'. For we know how much energy and acumen Erasmus put into the construction of an image of himself as an essentially impartial scholar. ${ }^{40}$

This brings us to a third and final element in Bayle's appropriation of Erasmus, who has often been called the first 'president' or even 'monarch' of the 'imagined community' of European scholars called the 'Republic of Letters'. ${ }^{41}$ Much has recently been written about its reality during the early modern age, about its allegedly secularist leanings and its fate during the High Enlightenment. One of the issues which keeps the experts divided is the extent to which during the eighteenth century it remained a unity. ${ }^{42}$ This much is certain, however, that if on the eve of the eighteenth century any single scholar in Europe could have been crowned Erasmus' successor, Pierre Bayle, who in 1684 launched his own Nouvelles de la République des Lettres, was the most obvious candidate. ${ }^{43}$ The main difference, or so it would seem to me, between the Republic of Letters of the early sixteenth and the late seventeenth centuries was the rise in prestige Bayle personally witnessed of the natural sciences and mathematics. To put it simply: although Erasmus was a contemporary of Copernicus, he never lived to see the publication of De revolutionibus orbium (1543). Bayle, on the other hand, was born five years after Galileo died in 1642 and only three years before Descartes passed away in Stockholm.

Most experts agree that Bayle's point of departure in philosophy was Cartesianism. ${ }^{44}$ Todd Ryan recently commented that for Bayle 'the seventeenth century is defined by Cartesianism, which he considers to be the most

40 Lisa Jardine, Erasmus, Man of Letters. The Construction of Charisma in Print, Princeton, 1993. See also Bruce Mansfield, Erasmus in the Twentieth Century. Interpretations, crg20-20oo, Toronto, 2003, Chapter 6.

41 Peter Burke, 'Erasmus and the Republic of Letters', European Review 7 (1999), pp. 5-17.

42 See most notably Dena Goodman, The Republic of Letters. A Cultural History of the French Enlightenment, Ithaca N.Y., 1994; Hans Bots and Françoise Wacquet, La République des Lettres, Paris, 1997; Anne Goldgar, Impolite Learning. Conduct and Community in the Republic of Letters, 1680-1750, New Haven, 1995; L.W.B. Brockliss, Calvet's Web. Enlightenment and the Republic of Letters in Eighteenth-Century France, Oxford, 2002; Constance M. Furey, Erasmus, Contarini, and the Religious Republic of Letters, Cambridge, 2006.

43 Hubert Bost, Un 'intellectuel' avant la lettre: le journaliste Pierre Bayle. L'actualité religieuse dans les Nouvelles de la République des Lettres (1684-1687), Amsterdam, 1994.

44 See also my 'Pierre Bayle on the History of Science: What Counts and What Does Not?' (forthcoming). 
sophisticated and compelling Christian philosophy yet devised.45 Bayle's Cartesian sympathies are amply confirmed by his adulation of mathematics, and geometry in particular. I am not sure how much Bayle actually knew about mathematics, or how good he was at it-some scholars may well have been a bit too hasty in claiming that his 'bagage mathématique' was 'minime', but he knew full well that his own talents were elsewhere. ${ }^{46}$ Much as he admired the recent progress science had made, the way in which he felt compelled to speak out in favour of what today we have come to call the humanities speaks volumes: 'Or qui peut douter', Bayle mused in the Nouvelles de la République des Lettres:

qu'il y ait des Humanistes aussi dignes d'admiration que les plus subtils Mathématiciens, puisqu'il est indubitable qu' il y a des difficultez de Chronologie et de Critique pour l' explication desquelles il faut un aussi grande quantité d'esprit, si j' ose parler ainsi, que pour la résolution des plus difficiles Problèmes de Géométrie. ${ }^{47}$

Commenting on Bayle's assessment of the sciences, Élisabeth Labrousse already pointed to the 'similitudes essentielles' Bayle acknowledged between the exact sciences and the humanities. But his plea in favour of the unity of Science is qualified by an interesting discussion: while some domains of knowledge are merely 'utile', others seem mainly 'agréable'48 In the introduction to his Projet et Fragments of 1692 Bayle even attacked the utilitarian approach to the sciences that would result in the exclusive cultivation of 'the mechanic arts': 'Pour tous professeurs, on n' aurait Presque des Ingénieurs, qui ne feroient qu' inventer de nouveaux moïens de faire périr beaucoup de monde. 49 Bayle, for his part, insisted that the humanities are not only 'agréable'. They also serve a wider, moral purpose: 'en vain chercheroit-on ces utilitez morales dans un receuil de quintessences d'algèbres. ${ }^{50}$ Bayle's emphasis on the moral impact of the writing of history next inspired him to remark that it is just

45 Todd Ryan, Pierre Bayle's Cartesian Metaphysics. Rediscovering Early Modern Philosophy, New York, 2009, p. 8.

46 Labrousse, Hétérodoxie et rigorisme, p. 219.

47 Pierre Bayle, Oeuvres Diverses, 4 vols., La Haye, 1727-1731, Ia, p. 125, quoted from Labrousse,

Hétérodoxie et rigorisme, p. 7.

48 Élisabeth Labrousse, Hétérodoxie et rigorisme, p. 7.

49 Pierre Bayle, Projet et Fragments d'un Dictionnaire critique, Rotterdam, 1692, Preface, n.p. 5o Ibid. 
as difficult to establish truths in history as it is to draw a valid mathematical inference, which appears to confirm the deeply Calvinistic attitude of $l e$ philosophe de Rotterdam towards truths that matter. The immense effort it takes to find out the truth about our past also serves as a reminder that we are finite, feeble and fragile. The many mistakes we make as historians 'sont autant de trophées ou autant d'arcs de triomphe erigez à l'ignorance et à la foiblesse humaine. ${ }^{51}$

It is not easy to situate Bayle in the history of philosophy, and in view of Descartes' own attacks on erudition, the 'erudite Cartesian', or, for that matter, the 'Erasmian Cartesian' Bayle was, may indeed look like a paradox. ${ }^{52}$ From a contemporary perspective another 'paradox' of Bayle's position results from the essentially a-historical, positivist conception of the progress of science Bayle eschews - from Magic to Mathematics, and from Darkness into the Light. For in his assessment of the sciences he seems mainly concerned to separate Philosophy from Theology and to establish the damage done by such pseudosciences as Astrology, Millenarianism and all other attempts at Soothsaying in general. ${ }^{53}$ Bayle's optimism, however should not be overestimated. He just revelled in exposing scholarly frauds and scientific charlatans, who to his mind displayed moral shortcomings in that they were unable to resist the temptation to pose as prophets. Perhaps the 'erudite Cartesian' should not be regarded a paradox either, but rather, as Anthony Grafton has suggested, as an attempt to lend prestige to erudition and historical scholarship as such, at a moment in early modern history when their status was being questioned severely. ${ }^{54}$

Some of the finest historians have warned us of the dangers of projecting the essentially nineteenth-century distinction between Natur- und Geisteswissenschaften onto the late seventeenth-century Republic of Letters. ${ }^{55}$ As a

51 Ibid.

52 Élisabeth Labrousse, Notes sur Bayle, Paris, 1987 , Chapter 7.

53 See, for instance, Hubert Bost, 'Les faux prophètes dans le Dictionaire de Pierre Bayle: fanatiques ou imposteurs?', Hans Bots (ed.), Critique, savoir et érudition à la veille des Lumières. Le Dictionaire historique et critique de Pierre Bayle (1647-1706), Amsterdam, 1998, pp. 235-249; J.C. Laursen, 'Bayle's Anti-Millenarianism: The Dangers of Those Who Claim to Know the Future', J.C. Laursen and R.H. Popkin (eds.), Millenarianism and Messianism in Early Modern European Culture, Dordrecht, 2001, pp. 95-106; Koen Vermeir, 'The Dustbin of the Republic of Letters. Pierre Bayle's Dictionaire as an Encyclopedic Palimpsest of Errors', Journal of Early Modern Studies 1 (2012), pp. 109-149.

54 Anthony Grafton, The Footnote. A Curious History, London, 1997, Chapter 7.

55 See for instance Anthony Grafton, Defenders of the Text. The Traditions of Scholarship in an Age of Science, 1450-180o, Cambridge Mass., 1991; Paula Findlen, Possessing Nature. Museums, 
historian Bayle was still part of an intellectual culture in which scholarly and scientific pursuits were often hard to distinguish. In late seventeenth-century Europe, the 'Two Cultures' C.P. Snow spoke about in his famous 1959 lecture still belonged to a common pursuit, although in philosophy the status of natural philosophy was rapidly growing. In fact, from a late seventeenth-century perspective, it very much remains to be seen whether Erasmus could be regarded as a philosopher at all. Today, most experts seem to agree that during the seventeenth century Philosophy was largely defined by the ongoing battle between representatives of Aristotelianism and a series of novatores, including Bacon, Gassendi, Descartes and Hobbes, who were all eager to offer an alternative to the Aristotelian world view, which gradually disintegrated, in particular once its natural philosophy was no longer able to accommodate the latest findings of the 'sciences'. Astronomy, medicine and physics, which until the first half of the eighteenth century was most often simply referred to as 'natural philosophy', gradually abandoned the conceptual vocabulary of the Peripatetic tradition. Several mechanist alternatives were put forward, and in the process both metaphysics and the theory of knowledge profited considerably, for the new philosophies of nature called for a new understanding both of the ultimate structure of reality and of man's cognitive access to nature. ${ }^{56}$ So the special veneration in which Erasmus was held by le philosophe de Rotterdam is all the more remarkable: Erasmus was no metaphysician, no natural philosopher and did not espouse any sophisticated epistemology either. From a philosophical perspective, Erasmus was essentially a moral philosopher. ${ }^{57}$ Bayle's

Collecting and Scientific Culture in Early Modern Italy, Berkeley, 1994; Lorraine Daston, Wonders and the Order of Nature, 1150-1750, New York, 1997; Eric Jorink, Reading the Book of Nature in the Dutch Golden Age, Leiden, 2010.

$5^{6}$ The literature is, of course, immense, and it would be folly to supply a relevant 'bibliography'. For a particularly forceful, recent attempt to integrate the rise of science and the history of philosophy, see Stephen Gaukroger, The Emergence of a Scientific Culture. Science and the Shaping of Modernity, 1210-1685, Oxford, 2006 and The Collapse of Mechanism and the Rise of Sensibility, Oxford, 2010.

57 Knud Haakonssen, it should be added, accuses the dominant perception of early modern philosophy as a project essentially concerned with metaphysics and the theory of knowledge of suffering from an essentially Kantian 'epistemological bias', obscuring the part played by social, moral and political philosophy: 'The Idea of Early Modern Philosophy', J.B. Schneewind (ed.), Teaching New Histories of Philosophy, Princeton N.J., 2004, pp. 99-121. For two recent perspectives on Erasmus as a moral philosopher, see Han van Ruler, '“Quid aliud est, quam insanire?" Erasmus, Valla and the Stoic-Epicurean Controversy', Pasini and Rossi (eds.), Erasmo da Rotterdam, pp. 175-197; Jill Kraye, 'Pagan Philosophy and Patristics in Erasmus and His Contemporaries', Erasmus of Rotterdam Society Yearbook 31 (2011), pp. 33-6o. 
admiration, however, does not seem to have been inspired by Erasmus' philosophical achievements. Bayle admired Erasmus as a historian.

Ruth Whelan has studied Bayle's practice as a historian, and following Labrousse, she has emphasised the importance of both humanist historiography and of the 'Augustino-Calvinist anthropology' at work in Bayle's writings: in his opinion, Whelan argues, the reasonable, 'enlightened' historian has to take precedence over the 'historien passioné. ${ }^{58}$ Just as 'prophets' need to be scrutinised over their motives, historians have to be examined critically over their personal involvement with the past. The purpose of enlightened scholarship according to Bayle is to create a community held together by the shared pursuit of reason and truth. This community is, of course, the Republic of Letters. In the Preface to the Nouvelles de la République des Lettres, the journal Bayle started in 1684, he was, again, at pains to exclude religious considerations from this pursuit:

Il ne s' agit point ici de Religion; il s' agit de Science: on doit donc mettre bas tous les termes qui divisent les hommes en differentes factions, et considerer seulement le point dans lequel ils se réünissent ...59

Over the past few decades some of the finest Bayle scholars have turned le philosophe de Rotterdam into an essentially irreligious philosopher, but clearly his 'separatism' alone does not entail any secularism at all. ${ }^{60}$ Bayle's insistence on the need to separate Reason from Faith also served to keep faith pure, and Erasmus could hardly have disagreed. In philosophy, not only did Bayle share Erasmus' hesitations regarding Scholasticism, but even his insistence on the possibility of virtuous atheism seems to fit hand in glove with Erasmus' insistence on the need for a Philosophia Christi; for Bayle's critique of revealed religion is based first and foremost on the perfectly Erasmian recognition of the habitual failure of Christians to practice what they preach. Despite his

$5^{8}$ Ruth Whelan, The Anatomy of Superstition. A Study of the Historical Theory and Practice of Pierre Bayle, Oxford, 1989, p. 63.

59 Quoted in Whelan, The Anatomy of Superstition, p. 87.

60 David Wootton, 'Pierre Bayle, Libertine?', M.A. Stewart (ed.), Studies in Seventeenth-Century European Philosophy, Oxford, 1997, pp. 197-226; Gianluca Mori's Bayle philosophe, Paris, 1999; Jonathan I. Israel, Radical Enlightenment. Philosophy and the and the Making of Modernity, 1650-1750, Oxford, 2001, Chapter 18; Antony Mckenna, 'Pierre Bayle in the Twentieth Century', Wiep van Bunge and Hans Bots (eds.), Pierre Bayle (1647-1706), le philosophe de Rotterdam, Leiden, 2008, pp. 253-268. 
occasional flirt with Epicureanism, Bayle does not argue in favour of any pagan morality. Following Erasmus, he is mainly concerned to establish the abominable difference among both Catholics and Protestants between 'ce qu' on croit et ce qu' on fait'.61

\section{Conclusion}

In conclusion, Bayle's failed attempt to save his career at the Illustrious School of Rotterdam by turning to Erasmus tapped into a long, local tradition of civic pride: as Rotterdam has always been associated with trade and commerce, rather than with science, scholarship, and other instances of 'high culture', Rotterdam elites have persistently cultivated the fact that this great humanist was born in their city. More recently, the appropriation of Erasmus has also produced a wide variety of politically motivated initiatives, focussing on his 'tolerant' 'cosmopolitanism'. In Bayle it resulted in a picture of Erasmus that would become highly influential, in particular during the Enlightenment. By the same token Bayle's account of Erasmus appears to have been based on a genuine sense of affinity. Besides a common penchant for fideism and pacifism, they shared, or so Bayle must have felt, another cause as well, for both were scholars, dedicated to the quest of establishing historical, that is essentially: textual accuracy. Originally, Bayle's Dictionary was conceived as a compilation of long lists of errors made by previous authors. ${ }^{62}$ His insistence on the need for any historian to be critical, that is to correct the countless mistakes made by his predecessors echoes Erasmus' complaints about the difficulties involved in editing ancient texts: 'it cost Jerome less to write his works than it has cost me to restore and explain them', and 'I cannot think that Hercules consumed as much energy in taming a few monsters as I did in abolishing so many thousand blunders. ${ }^{\prime} 3$ For in the end, Bayle and Erasmus shared nothing so much as a deep felt awareness of the fragility of human nature.

61 Pierre Bayle, Pensées diverses sur la comète, eds. Joyce and Hubert Bost, Paris, 2007, p. 291.

62 On the relationship of the Projet to the Dictionnaire, see H.H.M. van Lieshout, De wordingsgeschiedenis van de Dictionaire Historique et Critique van Pierre Bayle (1689-1706), Grave, 1992, pp. 7-13.

63 Quoted from Jardine, Erasmus, pp. 68 and 72. 